\title{
PENGARUH METODE PEMBELAJARAN DAN KECERDASAN SOSIAL TERHADAP HASIL BELAJAR IPS SISWA KELAS IV SEKOLAH DASAR BANDA ACEH
}

\author{
Alpidsyah Putra \\ Universitas Samudra \\ alpidsyahputra@gmail.com
}

\begin{abstract}
This study aimed to determine the effect of learning methods and social intelligence to the learning outcomes of social science. This research was conducted with the experimental method in the fourth grade students of State Elementary School Banda Aceh in 2015 with 32 samples taken using cluster random sampling. Retrieval of data obtained through analysis test Varian (ANOVA) two-lane design treatmeant by level $2 \mathrm{x}$ 2. The results showed that: (1) results for students studying social sciences with teaching methods problem based learning is higher than the students who use the method learning problem solving, (2) There is an interaction effect between teaching methods with social intelligence of students towards learning outcomes of social science, (3) results of studying social science students who have social intelligence higher learning with teaching methods problem based learning higher the method of problem solving, (4) Results of studying social science students with low social intelligence learning with the learning method of problem-based learning is lower than the learning method of problem solving. The results of this study indicate that the learning method of problem based learning with high social intelligence can improve learning outcomes of social science.
\end{abstract}

Keywords: Learning Method, Social Intelligence, Social Science Learning Outcomes

\begin{abstract}
Abstrak: Penelitian ini bertujuan untuk mengetahui pengaruh metode pembelajaran dan kecerdasan sosial terhadap hasil belajar Ilmu Pengetahuan Sosial. Penelitian ini dilakukan dengan metode experimen pada siswa kelas IV Sekolah Dasar Negeri Banda Aceh pada tahun 2015 dengan 32 sampel diambil dengan menggunakan cluster random sampling. Pengambilan data diperoleh melalui tes analisis Varian (ANAVA) dua jalur dengan desain treatmeant by level $2 \times 2$. Hasil penelitian menunjukkan bahwa : (1) Hasil belajar ilmu pengetahuan sosial siswa dengan menggunakan metode pembelajaran problem based learning lebih tinggi dari pada siswa yang menggunakan metode pembelajaran problem solving, (2) Terdapat pengaruh interaksi antara metode pembelajaran dengan kecerdasan sosial siswa terhadap hasil belajar ilmu pengetahuan sosial, (3) Hasil belajar ilmu pengetahuan sosial siswa yang memiliki kecerdasan sosial tinggi yang belajar dengan menggunakan metode pembelajaran problem based learning lebih tinggi dari pada menggunakan metode problem solving, (4) Hasil belajar ilmu pengetahuan sosial siswa dengan kecerdasan sosial rendah yang belajar dengan metode pembelajaran problem based learning lebih rendah dibandingkan dengan metode pembelajaran problem solving. Hasil penelitian ini menunjukkan bahwa metode pembelajaran problem based learning dengan kecerdasan sosial tinggi dapat meningkatkan hasil belajar Ilmu Pengetahuan Sosial
\end{abstract}

Kata Kunci : Metode Pembelajaran, Kecerdasan Sosial, Ilmu Pengetahuan Sosial 
Pembelajaran merupakan proses interaktif yang berlangsung antara guru, siswa dangan materi yang akan dipelajari, hasil pelajaran tidak tergantung pada apa yang disampaikan guru, tetapi bagaimana siswa mengolah informasi yang diterima. Dalam kegiatan pembelajaran guru harus memandang siswa sebagai manusia yang memiliki potensi intelektual, oleh karena itu, peran guru tidak hanya memberikan informasi saja melaikan harus membimbing siswa agar berperan lebih aktif, hal ini sudah menjadi tugas guru untuk menciptakan suasana belajar yang mendukung metode pembelajaran yang relevan.

Hal ini sebagai salah satu upaya untuk mencerdaskan kehidupan bangsa sehingga menghasilkan output yang baik, hal ini dapat terlihat dari hasil belajar, hasil belajar yang baik tersebut harus dimiliki oleh siswa untuk semua pembelajaran dikelas, salah satunya adalah mata pelajaran Ilmu Pengetahuan Sosial. Trianto (2010: 171) menjelaskan ilmu Pengetahuan Sosial merupakan intergrasi dari berbagai cabang ilmu-ilmu sosial, seperti sosiologi, sejarah, geografi, ekonommi, politik, hukum dan budaya.

Salah satu penyebab siswa kurang berminat terhadap mata pelajaran Ilmu Pengatahuan Sosial karena guru hanya melakukan pembelajaran dengan metode konvensional, metode ini sebenarnya sudah tidak layak digunukan dalam proses pembelajaran dan perlu diubah, tetapi untuk mengubah metode pembelajaran ini sangat susah karena guru harus memiliki kemampuan dan keterampilan dalam menggunakan metode pembelajaran yang lain.

Salah satu metode pembelajaran yang bisa digunakan dalam mencapai tujuan pendidikan Ilmu Penggetahuan Sosial adalah metode pembelajaran Problem Based Learning yang secara langsung dapat membangkitkan kemampuan berpikir siswa untuk memberikan solusi terhadap suatu masalah. Dalam metode ini menawarkan kebebasan siswa dalam proses pembelajaran. Panen dalam Rusmono (2012:74) mengatakan dalam strategi pembelajaran dengan PBL, siswa diharapkan untuk terlibat dalam proses penelitian yang mengaharuskannya untuk mengidentifikasi permasalahan, pengumpilan data, dan menggunakan data tersebut untuk pemecahan masalah.

Lebih lanjut, Delisle dalam Tan (2003:30) menjelaskan problem based learninig work well with all student, making its strategies ideal for heterogeneous classrooms where students with mixed abilities can pool their talents 
collaborativeley to invent a solution. Yaitu

Problem Based Learning cocok digunakan untuk semua siswa, metode tersebut ideal untuk kelas yang heterogen dimana siswa dengan kemampuan akademik yang beragam dapat bekerja sama untuk menghasilkan pemecahan masalah. Amir (2009: 73-79) menjelaskan tujuh langkah proses Problem Based Learning (1) mengklarifikasikan istilah dan konsep yang belum jelas (2) merumuskan masalah, (3) menganalisis masalah, (4) menanta gagasan anda secara sistematis menganalisisnya dengan dalam, (5) memformulasikan tujuan pembelajaran, (6) mencari informasi tambahan dari sumber lain (di luar diskusi kelompok), (7) mensintesis (menggambungkan) dan menguji informasi baru.

Metode lain yang bisa digunakan dalam pembelajaran Ilmu Penggetahuan Sosial yaitu metode pembelajaran Problem Solving yang melatih siswa untuk menemukan solusi dari masalah-masalah yang diasumsikan muncul dari pembelajaran Ilmu Pengetahuan Sosial. Dalam hal ini siswa dituntut melakukan analisis mendalam terhadap suatu permasalahan dan pada akhirnya menemukan solusi dari persoalan tersebut kemudian diberikan penilaian.
Menurut Alma (2010: 91) Metode Problem Solving adalah metode pembelajaran yang bersifat mencari solusi secara logis, kritis, analitis menuju kesimpulan yang meyakinkan. Schunk (2012: 416) menjelaskan bahwa metode problem solving bukan saja merupakan metode pembelajaran akan tetapi juga merupakan suatu metode berpikir karena didalamnya menggunakan metode lainnya yang dimulai dengan mencari data sampai menarik kesimpulan. Metode ini juga merupakan salah satu metode pembelajaran yang menyenangkan dan menuntut keaktifan siswa dalam mencapai tujuan pembelajaran.

Selain penggunaan metode pembelajaran, guru harus memperhatikan kecerdasaan yang dimiliki oleh siswa. Dua kecerdasan yang harus diperhatikan yaitu kecerdasan sosial yang biasa disebut kecerdasan interpersonal dan kecerdasan intrapersonal. Menurut Thorndike dalam buku Herrsten (1973: 12) kecerdasan sosial "the ability to understand other and act wisely in human relations". Kecerdasan ini berbeda dengan kemampuan akademik dan merupakan unsur utama yang membuat orang berhasil dalam hidupnya. kecerdasan ini yang berpengaruh setelah belajar Ilmu Pengetahuan Sosial. 
Goleman (2007:114) menyatakan ada dua komponen utaman dalam membangun kecerdasan sosial yang baik yaitu kesadaran sosial dan fasilitas sosial, kesadaran sosial adalah apa yang kita rasakan tentang orang lain, kesadaran sosial merujuk pada spektrum yang merentang dari secara instan merasakan keadaan batiniah orang lain sampai memahami perasaan dan pikirannya untuk mendapatkan situasi sosial yang rumit.

\section{METODE}

Penelitian ini dilaksanakan dengan menggunakan metode eksperimen dengan rancangan desain treatment by level $2 \times 2$, dengan eksperimen ini peneliti mencoba metode pembelajaran Problem Based Learning dengan metode pembelajaran Problem Solving subjek penelitian dibagi atas dua kelas yaitu kelas eksperimen dan kelas kontrol. Kelas eksperimen diajarkan dengan motede pembelajaran Problem Based Learning dan kelas kontrol diajarkan dengan metode pembelajaran Problem Solving, sedangkan variable atribut diklasifikasikan menjadi kecerdasan sosial tinggi dan rendah.

Jumlah keseluruhan siswa yang menjadi subjek penelitian adalah 59 orang, yang dibagi ke dalam dua kelas (kelas A dan kelas B), masing-masing terdiri dari kelas A 29 siswa dan kelas B 30. Kemudian masing-masing siswa diberikan angket kecerdasan sosial. Skor dari pengisian angket tersebut kemudian disusun berdasarkan urutan dari skor tertinggi ke skor yang terendah.

Selanjutnya, pada setiap kelas ditetapkan $27 \%$ dari rangking teratas digolongkan sebagai kelompok siswa yang memiliki kecerdasan sosial tinggi dan $27 \%$ dari rangking terbawah digolongkan sebagai kelompok siswa yang memiliki kecerdasan sosial rendah. Dari tiap-tiap kelas diperoleh sebanyak $27 \%$ dari 30 orang yaitu 8 orang yang memiliki kecerdasan sosial tinggi dan 8 orang yang memiliki kecerdasan sosial rendah. Dengan demikian, maka distribusi siswa pada masing-masing taraf variable bebas dapat dilihat pada Table 1 berikut ini: 
Tabel 1. Distribusi Siswa Pada Masing-masing Variabel

\begin{tabular}{ccccc}
\hline Keecerdasan sosial & \multicolumn{2}{c}{ Metode Pembelajaran } & Jumlah \\
& PBL & Problem Solving & \\
\hline Tinggi & 8 & 8 & 16 \\
\hline Rendah & 8 & 8 & 16 \\
\hline Jumlah & 16 & 16 & 32 \\
\hline & & mata pelajaran & IPS antara & siswa yang
\end{tabular}

Hasil belajar Ilmu Pengetahuan Sosial diperoleh siswa setelah menjawab tes mata pelajaran Ilmu Pengetahuan Sosial pada akhir pelaksanaan penelitian yang berbentuk esay dengan materi Cita-citaku. Skor yang diperoleh siswa setelah menjawab kuesioner kecerdasan sosial yang terdiri dari empat jenjang pertanyaan dan merupaka skala ordinal.

Teknik analisis data yang diperlukan dalam penelitian ini adalah teknik analisis varian (ANAVA) dua ajlur, teknik ini dipilih karena peneliti ingin mengetahui perbedaan hasil belajar siswa yang dihasilakn melalui metode pembelajaran Problem Based Learning dan Pronblem Solving. Selain itu peniliti ingin mengetahui signifikansi interaksi yang terjadi antara metode pembelajaran dan kecerdasan sosial siswa terhadap hasil belajar Ilmu Pengetahuan Sosial.

\section{HASIL}

Hasil analisis dan deskripsi, peneliti melihat perbedaan hasil belajar siswa pada pembelajarannya menggunakan metode $\mathrm{PBL}$ dengan siswa yang pembelajarannya menggunakan PS. Skor rata-rata hasil belajar siswa pada mata pelajaran IPS untuk kelas PBL ada 79,9655 dengan standar deviasi 11,48. Kemudian terlihat juga bahwa skor maksimum adalah 98 dan skor minimum 55 dengan median 84. Skor rata-rata tersebut lebih tinggi dibandingkan dengan siswa yang pembelajarannya menggunakan metode PS, yaitu 64,6 dan standar deviasi 12,92. Kemudian untuk nilai maksimum 85 dan nilai minimum 35 dengan median 67.5.

Selain berdasarkan kelas pembelajaran kemampuan hasil belajar siswa pada mata pelajaran IPS juga dilihat berdasarkan kecerdasan sosial (tinggi dan rendah). Hal ini dikarenakan peneliti ingin melihat sejauh mana kecerdasan sosial memiliki pengaruh terhadap hasil belajar siswa pada mata pelajaran IPS. Skor rata-rata hasil belajar tertinggi didapat oleh kelompok PBL dengan kecerdasan tinggi dengan rata-rata 84,00; standar deviasi 10,32, kemudian nilai maksimum 98,00; minimum 57,00 dengan 
median 86,00. Urutan rata-rata kedua ditempati oleh kelompok PS kecerdasan tinggi dengan skor rata-rata hasil belajar peserta didik adalah 71,13; standar deviasi 6,70; kemudian nilai minimum 60 dan maksimum 85 dan nilai tengah (median) sebesar 71 .

Uratan ketiga skor rata-rata hasil belajar siswa adalah kelompok PBL kecerdasan rendah dengan skor rata-rata 69,37; standar deviasi 6,78; nilai maksimum 75 dan nilai minimum 55 dengan median 70. Sedangkan untuk uratan terakhir yaitu kelompok PS kecerdasan rendah dengan rata-rata 58,06; standar deviasi 14,46, nilai maksimum 84 dan minimum 35 dengan median 55.

Hipotesis pertama yang diajukan dalam penelitian ini menunjukkan bahwa $\mathrm{H}_{0}$ ditolak karena nilai signifikansi yaitu 0,000 kurang dari 0,05 dan dapat disimpulkan bahwa hasil belajar ilmu pengetahuan sosial siswa dengan menggunakan metode pembelajaran problem based learning lebih tinggi dari pada siswa yang menggunakan metode pembelajaran problem solving. Hal ini dapat dilihat pada Tabel 2 berikut ini :

Tabel 2. Uji T Independent Sampel T test Skor Hasil Belajar IPS Berdasarkan Model pembelajaran

\begin{tabular}{|c|c|c|c|c|c|c|c|c|}
\hline & & \multicolumn{7}{|c|}{ t-test for Equality of Means } \\
\hline \multirow{4}{*}{ Hasil_Belajar } & & & & & & & \multicolumn{2}{|c|}{$\begin{array}{l}95 \% \text { Confidence Interval of the } \\
\text { Difference }\end{array}$} \\
\hline & & $\mathrm{t}$ & df & $\begin{array}{l}\text { Sig. }(2- \\
\text { tailed) }\end{array}$ & $\begin{array}{l}\text { Mean } \\
\text { Difference }\end{array}$ & $\begin{array}{l}\text { Std. Error } \\
\text { Difference }\end{array}$ & Lower & Upper \\
\hline & $\begin{array}{l}\text { Equal } \\
\text { variances } \\
\text { assumed }\end{array}$ & 4.823 & 57 & .000 & 15.36552 & 3.18609 & 8.98547 & 21.74556 \\
\hline & $\begin{array}{l}\text { Equal } \\
\text { variances not } \\
\text { assumed }\end{array}$ & 4.832 & 56.612 & .000 & 15.36552 & 3.17967 & 8.99740 & 21.73364 \\
\hline
\end{tabular}

Hipotesis kedua ingin membuktikan sejauh mana kecerdasan sosial berpengaruh terhadap hasil belajar maka dilakukan dengan uji anova dua jalur yang terlebih dahulu dilakukan kruskal wallis, hasilnya dapat dilihat pada Tabel 3 sebagai berikut: 
Tabel 3.Hasil Rekapitulasi Interkasi Antara Metode Pembelajaran dan Kecerdasan Sosial terhadap Hasil Belajar Mata Pelajaran IPS

\begin{tabular}{|c|c|c|c|c|c|}
\hline \multicolumn{6}{|c|}{ Tests of Between-Subjects Effects } \\
\hline \multicolumn{6}{|c|}{ Dependent Variable:Hasil_Belajar } \\
\hline Source & $\begin{array}{l}\text { Type III Sum of } \\
\text { Squares }\end{array}$ & $\mathrm{df}$ & Mean Square & $\mathrm{F}$ & Sig. \\
\hline Corrected Model & $6001.085^{\mathrm{a}}$ & 3 & 2000.362 & 18.298 & .000 \\
\hline Intercept & 260983.851 & 1 & 260983.851 & $2.387 \mathrm{E} 3$ & .000 \\
\hline Kelas & 1910.201 & 1 & 1910.201 & 17.474 & .000 \\
\hline Kecerdasan_Sosial & 2506.365 & 1 & 2506.365 & 22.927 & .000 \\
\hline Kelas * Kecerdasan_Sosial & 7.937 & 1 & 7.937 & .073 & .009 \\
\hline Error & 6012.542 & 55 & 109.319 & & \\
\hline Total & 319167.000 & 59 & & & \\
\hline Corrected Total & 12013.627 & 58 & & & \\
\hline
\end{tabular}

a. R Squared $=, 500$ (Adjusted R Squared $=, 472$ )

Terlihat berdasarkan Tabel 2 kelas dengan kecerdasan sosial berinteraksi hal ini dikarenakan nilai signifikansi 0,009 kurang dari 0,05 , sehingga $\mathrm{H}_{0}$ ditolak sehingga dapat disimpulkan bahwa Terdapat pengaruh interaksi anatara metode pembelajaran dengan kecerdasan sosial siswa terhadapat hasil belajar ilmu pengetahuan sosial.

Hipotesis Ketiga dan Keempat dapat dijawab dengan uji ANOVA dengan terlebih dahulu dilakukan uji Kruskal wallis, hasil ujinya pada Tabel 5 sebagai berikut:

Untuk melihat perbedannya dilanjutkan dengan uji T pada Tabel 5 sebagai berikut:

Tabel 5. Rekapitulasi Uji Tuckey

\begin{tabular}{|c|c|c|c|c|c|c|}
\hline \multicolumn{7}{|c|}{ Multiple Comparisons } \\
\hline \multicolumn{7}{|l|}{$\begin{array}{l}\text { Hasil_Belajar } \\
\text { Scheffe }\end{array}$} \\
\hline & & Mean & & & \multicolumn{2}{|c|}{$\begin{array}{l}\text { 95\% Confidence } \\
\text { Interval }\end{array}$} \\
\hline (I) Grup & (J) Grup & $\begin{array}{l}\text { Difference } \\
\quad(\mathrm{I}-\mathrm{J})\end{array}$ & $\begin{array}{l}\text { Std. } \\
\text { Error }\end{array}$ & Sig. & $\begin{array}{l}\text { Lower } \\
\text { Bound }\end{array}$ & $\begin{array}{l}\text { Upper } \\
\text { Bound }\end{array}$ \\
\hline \multirow{3}{*}{$\begin{array}{l}\text { PBL } \\
\text { Kecerdasan } \\
\text { Sosial Tinggi }\end{array}$} & $\begin{array}{l}\text { PBL Kecerdasan Sosial } \\
\text { Rendah }\end{array}$ & $14.6250^{*}$ & $\begin{array}{r}4.3440 \\
2\end{array}$ & .015 & 2.0967 & 27.1533 \\
\hline & $\begin{array}{l}\text { PS Kecerdasan Sosial } \\
\text { Tinggi }\end{array}$ & $12.8667^{*}$ & $\begin{array}{r}3.5346 \\
3\end{array}$ & & 2.6727 & 23.0606 \\
\hline & $\begin{array}{l}\text { PS Kecerdasan Sosial } \\
\text { Rendah }\end{array}$ & $25.9333^{*}$ & $\begin{array}{r}3.5346 \\
3\end{array}$ & .000 & 15.7394 & 36.1273 \\
\hline \multirow{2}{*}{$\begin{array}{l}\text { PBL } \\
\text { Kecerdasan } \\
\text { Sosial Rendah }\end{array}$} & $\begin{array}{l}\text { PBL Kecerdasan Sosial } \\
\text { Tinggi }\end{array}$ & $-14.6250^{*}$ & $\begin{array}{r}4.3440 \\
2\end{array}$ & .015 & -27.1533 & -2.0967 \\
\hline & $\begin{array}{l}\text { PS Kecerdasan Sosial } \\
\text { Tinggi }\end{array}$ & -1.7583 & $\begin{array}{r}4.5774 \\
2\end{array}$ & & 7 & 11.4431 \\
\hline
\end{tabular}




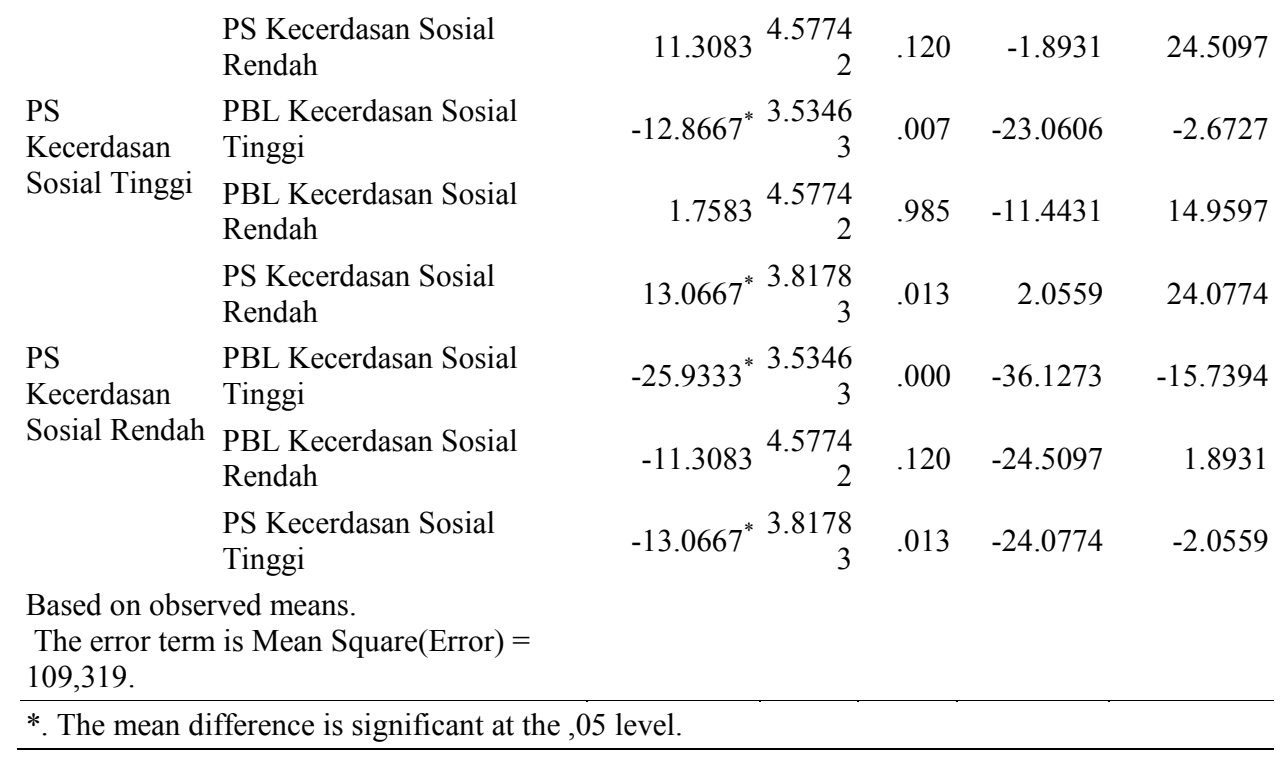

Pada Tabel 4 terlihat bahwa untuk menguji hipotesis ke-3 dan ke-4 dapat dilihat pada tabel yang telah dibulati. Untuk hipotesis ke-3 $\mathrm{H}_{0}$ ditolak dengan demikian dapat disimpulkan Hasil belajar ilmu pengetahuan sosial siswa yang memiliki kecerdasan sosial tinggi yang belajar dengan menggunakan metode pembelajaran problem based learning lebih tinggi dari pada menggunakan metode problem solving.

Untuk hipotesis keempat nilai signifikansi diatas 0,05 dengan demikian dapat disimpulkan bahwa Hasil belajar ilmu pengetahuan sosial siswa dengan kecerdasan sosial rendah yang belajar dengan metode pembelajaran problem based learning lebih rendah dibandingkan dengan metode pembelajaran proble solving.

Berdasarkan tabel perhitungan uji statistik yang dibahas sebelumnya bahwa dapat disimpulkan hasil belajar siswa yang pembelajarannya menggunakan metode PBL lebih baik dibandingkan dengan siswa yang pembelajarannya menggunakan metode PS. Hal itu sesuai dengan karakteristik pembelajaran Problem Based Learning (PBL) menurut Nurhadi (2004: 60) yang menjelaskan bahwa PBL memiliki tahapantahapan yaitu 1) orientasi siswa pada masalah,2) mengorganisir siswa untuk belajar, 3) membimbing penyelidikan individual dan kelompok, 4) mengembangkan dan menyajikan hasil kerja, 5) menganalisis dan mengevaluasi pemecahan masalah.

\section{PEMBAHASAN}

Hasil penelitian menunjukkan bahwa terdapat interaksi antara metode pembelajaran dengan kecerdasan sosial terhadap hasil belajar siswa pada mata pelajaran IPS.Ini menunjukan kepada kita bahwa metode 
pembelajaran memiliki kontribusi terhadap hasil belajar siswa, kemudian kecerdasan siswa juga memiliki kontribusi terhadap hasil belajar, artinya kedua variable tersebut memiliki pengaruh terhadap hasil belajar siswa pada mata pelajaran IPS. Hal ini didukung oleh pendapat English (2012 :143175) yang menjelaskan Kecerdasan sosial adalah kemampuan untuk memahami dan membuat perbedaan-perbedaan pada suasana hati, maksud, motivasi, dan prasaan terhadap orang lain, hal ini mencakup kepekaan dan ekpresi wajah, suara, gerak tubuh, kemampuan untuk membedakan jenis isyarat interpersonal dan kemampuan untuk merespon secara efektif isyarat-isyarat tersebut dalam beberapa cara pragmatis. Kecerdasan dapat memberikan pengaruh terhadap hasil belajar peserta didik dalam proses pembelajaran hal ini terbukti dengan terdapat interaksi antara kecerdasan sosial memiliki kontribusi terhadap hasil belajar. Hal ini sesuai dengan pendapat kecerdasan interpersonal adalah kemampuan memahami dan berinteraksi secara baik dengan orang lain, kemampuan ini melibatkan penggunaan berbagai keterampilan, verbal dan non verbal, kemampuan kerja sama, manajemen konflik, strategi membangun konsensus, kemampuan untuk percaya, menghormati, memimpin dan memotivasi orang lain untuk mancapai tujuan umum.

\section{SIMPULAN}

Berdsarkan hasil temuan dan pembahasan mengenai tes hasil belajar siswa pada mata pelajaran IPS melalui metode pembelajaran Problem Based Learning dan siswa yang pembelajarannya menggunakan metode pembelajaran Problem Solving, diperoleh beberapa kesimpulan yaitu, 1) hasil belajar ilmu pengetahuan sosial siswa dengan menggunakan metode pembelajaran problem based learning lebih tinggi dari pada siswa yang menggunakan metode pembelajaran problem solving, 2) terdapat pengaruh interaksi antara metode pembelajaran dengan kecerdasan sosial siswa terhadap hasil belajar ilmu pengetahuan sosial, 3) hasil belajar ilmu pengetahuan sosial siswa yang memiliki kecerdasan sosial tinggi yang belajar dengan menggunakan metode pembelajaran problem based learning lebih tinggi dari pada menggunakan metode problem solving, 4) hasil belajar ilmu pengetahuan sosial siswa dengan kecerdasan sosial rendah yang belajar dengan metode pembelajaran problem based learning lebih rendah dibandingkan dengan metode pembelajaran proble solving.

\section{DAFTAR RUJUKAN}

Alma, Buchari et al. 2010. Guru professional: Menguasai Metode Dan Terampil Mengajar. Bandung: Rineka Cipta. 
Amir, M. Tuafik. 2009. Inovasi Pendidikan

Melalui Problem Based Learning.

Jakarta: Kencana.

English ,Evelyn William. 2012. Mengajar Dengan Empati: Panduan Mengajar Ynag Tepat Dan Menyeluruh Untuk Ruang Kelas Dengan Kecerdasan Beragam, Terjemahan, Fuad Ferdinan. Bandung: Nuansa Cendekia.

Goleman, Daniel. 2007. "Social Intelegence: The New Science Of Human Relationship" Terjemahan. Jakarta: Gramedia Pustaka Utama.

Hernstein, R.J. I.Q. 1973. In The Meritocracy. Boston: Atlantic Monthly Press.

Nurhadi. 2004. Pembelajaran Konstektual dan Penerapannya dalam KBK. Malang: UM.

Rusmono. 2012. Strategi Pembelajran Dengan Problem Based Learning Itu Perlu. Jakata: Ghalia Indonesia, 2012.

Schunk, Dale H. 2012. Learning Theories an Educational Perspective, terjemahan, Eva Hamdiah. Yogyakarta: Pustaka Pelajar

Tan, Oon-Sen. 2003. Problem-Based Leearning Innovation: Using Problem to Power Learning in the $21^{\text {st }}$ Century. Singapure: Cengange Learning.

Trianto. 2010. Model Pembelajaran Terpadu. Jakarta: Bumi Aksara. 